\title{
The Learning Innovations and Characteristics of Early Childhood Education Teachers in Disruptive Era
}

\author{
Zulherma
}

Early Childhood Education Department, Padang State University, Padang, Indonesia, zulherma@gmail.com

\begin{abstract}
In the era of industrial revolution 4.0 emerging new technologies which resulted in tremendous changes in almost all areas of human life, including education. Even the world of education, including getting a significant impact. If teachers do not make innovations in the learning process their role it will soon be moved and replaced by rapidly evolving technology in the 4.0 era of the industrial revolution. Technology even in a matter of days experiencing rapid change. Being faster, easier, more detail is even cheaper. Teacher otherwise concerned with the pace of technology has entered into the world of education quickly will soon be left behind. This paper aims to portray the innovative learning early childhood teachers as bearers of knowledge for children in this age disruptive. The world of education requires teachers who are ready to take a position at the forefront of the world where education has been transformed into it. Early childhood educators are required to optimize the learning process, planning, teaching, learning and evaluation that will increasingly shape their competence as a teacher characteristic of this era. The research method is a literature study with descriptive analysis techniques. The results showed that if early childhood teachers implement the learning process systematically exploit technological facilities at Industrial Revolution 4.0 era will provide a positive influence for the optimization of learning and personality development at the same time early childhood educators.
\end{abstract}

Keywords: teachers, disruptive era, characteristics, ECD

\section{INTRODUCTION}

Innovation is a form of renewal of learning in the learning process when the process of education faces many external changes in order to improve the quality of implementation of the learning process. This will have an effect on the performance characteristics of the teacher. Community early childhood educators will also be affected by the positive impact of advances in information technology are rapidly evolving that will lead to changes in the learning process for young children.

Innovation learning and innovation characteristic of early childhood education teachers is a step and the best methods for the challenges of disruptive era, the industrial revolution 4.0. Early childhood teachers as facilitators to facilitate early childhood in learning activities.

The purpose of the literature searching related to early learning innovation and the characteristics of early childhood education teacher in an era of disruptive building a horizon view of early childhood educators to become an integral part accompany the students on their age that lives in the development of information and communication technology flows very fast.

\section{LITERATURE REVIEW}

According to Kusuma (2010: 2) innovation is a result of the creation of something supposedly new that is intended to fix the problem, either in the form of ideas, goods, events, methods, and so on are carried out individually or in groups.

Learning innovations in this technology era, according Kampylis, Bocconi, Punie (2012), a thorough involvement of how to generate information and knowledge. This view differs from simply using technology in traditional teaching practices. Learning innovations can be widened in scope to the learning environment, both formal and informal.

Innovation characteristics of the teacher become a necessity because the teacher is the facilitator forefront of their intensive interaction with the students. In this strategic position teachers are required to develop his skills, his knowledge to bring new things in their classrooms. According to Komara (2014: 49), teachers who are able to innovate means signifies that teachers can develop creative ideas that in Japan the teachers do lesson study to test their teaching practices to be more effective.

Early childhood education is an education before primary education, which is a development efforts aimed for children from birth up to the age of six years are 
accomplished by providing stimulation of education to help the growth and development of the physical and spiritual so that children have the preparedness to enter further education, held in formal, non-formal and informal, which according to the Regulation of the Minister of Education and Culture of Indonesia Number 137 of 2014 emphasized on the growth and development: the religious and moral, physical, motor, cognitive, language, social, emotional, and art.

According to Handitya disruptive era (2018), relating to the change of concept in the world of technology known as the industrial revolution 4.0. 4.0 Industrial Revolution first introduced by Professor Klaus Schwab famous German economist in his book The Fourth Industrial Revolution.

According Zubaidah (2018), there are four domains of competence and character which is the attitude of teacher skills in the 21 st century, known as the $4 \mathrm{C}$ competence. a). Critical Thinking Skills, b). Creative Thinking Skills, c). Communications Skills, d). Collaborations Skill. Ministry of Education and Culture (2018: 2), has begun to implement international standards which require a high power of reason, or the Higher Order Thinking Skills

(HOTS) based 4C.

\section{RESEARCH METHODOLOGY}

This study is a qualitative research that is Library Research. According to Hadi (1995: 3), Library Research using books and literature carefully excavated the main source of research. This type of research is qualitative, which produces research in the records and description of the results of the book $=$ book or literature studied.

Qualitative research requires descriptive analysis. This method will provide an overview and analysis in the form of clear information related to innovative learning and teacher characteristics of early childhood education in the era of disruptive.

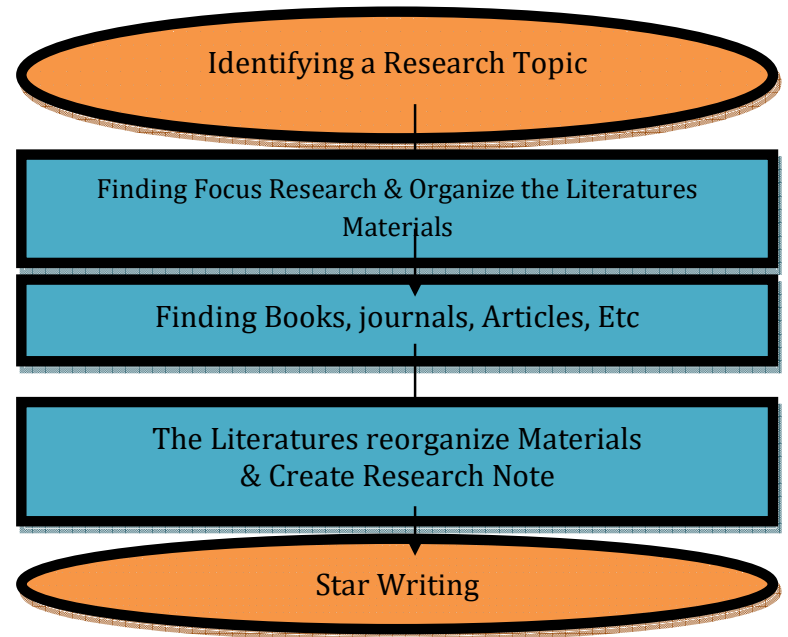

Figure 1. Steps to Write a Library Research

\section{RESULT AND DISCUSSION}

Teacher learning innovations and characteristics of early childhood education in the era of disruptive responded by Indonesia Governerment through Directorate General for Quality Improvement of Teachers and Educational Personnel (2018: 14), use the terms of the 4Cs (Critical Thinking, Communication, Collaboration, and creativity) as basic skills that identified as the 21 st century's skills. It is important that the skills needed for educational field at 21 century.

Framework competence skills of learners that are indispensable for the education of the 21st century, parts of Creativity Thinking and Innovation so that learners are able to produce, develop and implement their ideas creatively, while the other skill that is Critical Thinking and Problem Solving stimulate competence of learners in order to identify, analyze, interpret, and evaluate evidence, arguments, claims and data presented largely through in-depth assessment, as well as reflect it in our daily lives.

Communication, communication skills is one of the skills that support the future of learners to be able to communicate ideas and ideas effectively using oral media, written and technology. Collaborating on a group of skills in solving problems found within the competence of the $21 \mathrm{st}$ century skills that must be mastered learners.

For the role of the teacher as a facilitator for the attainment of these skills must be actualized from educator profession. The performance and function of teachers in developing the competence of learners will improve the quality of education in Indonesia.

Implementation of Curriculum 2013 oriented highlevel thinking skills in early childhood level aimed at achieving development. Teachers as educators in early childhood education need adaptation and make efforts to build character in activities to improve the competence of teachers. Teachers should not be satisfied with the ability of self.

In Indonesia, in order to meet the Industrial Revolution 4.0 government began to shift its focus from infrastructure development to human resource development (HRD). According to Amelia (2014), Education will accelerate the development of human resources. Quality education system has a strategic role in enhancing the intelligence of children, intellectually, emotionally and spiritually.

The low score of Indonesia on the Program for International Student Assessment (PISA) 2019, returned into the spotlight. PISA is an exam system that is initiated by the Organization for Economic Cooperation and Development (OECD), to evaluate education systems of 72 countries around the world. Every three years, the 15-year-old students were randomly selected to take the test on the three basic competencies of reading, mathematics and science. Indonesia PISA scores do not progress in $\mathbf{1 5}$ years, which is always under number 400. Meanwhile, countries of the Organization for Economic Cooperation and Development (OECD) have an average value above 500. This will give 
problems to our young people, because the evaluation results PISA is used to measure a student's readiness Indonesia in facing the future.

The low value of the three basic competence test of reading, math and science, and no increase in Indonesia PISA scores underlying the last 15 years researchers thought that it took control of this competence since early. Each competency will have a positive impact on the quality of self-learners.

Since early mastery of math concepts will be a strong foundation of future generations to master a variety of science and technology. Teachers should equip learners with the correct mathematical concepts, so with this by Rahmi (2013) will be born with the character generation disciplined, honest, hard working, creative, have a curiosity, responsible, communicative, independent.

Early childhood educators are a figure very important role in the learning process in early childhood classrooms. Professional teachers will create appropriate learning with early childhood. Characteristics of early childhood learning while playing so waking experience and knowledge of the real child. Children must be assured of the best things in the classroom so that it appears the quality of interaction quality that will bear meaningful experiences for their growth and development.

Early Childhood Education (ECD), Director General GTK ECD and Education Society (2018: 1), is one of the priority programs of education development in Indonesia. ECD success is inseparable from the role of early childhood educators or teachers in performing their role to guide, nurture, care for, educate and protect young children in order to maximize their growth and development.

An early childhood teacher will be able to understand, read and maximize the entire potential child. From here on it all the potential of children will be accommodated, mature and well targeted.

Act No. 20 of 2003 Chapter I Article 1 No. 14 which states "Early Childhood Education (ECD) is a development efforts aimed at children from birth up to the age of six years are accomplished by providing stimulus education to assist the growth and development physically and mentally so that children have the readiness to enter further education ".

In appendix 1 Permendikbud Decree No. 137 of 2014 On the National Standard of Early Childhood Education On Level Standards Achievement Development (STPPA) we can read there are six sphere of early childhood development, namely, religious values and moral, physical, motor, cognitive, language, social emotional and art.

Teachers at all levels are expected by the government to develop a learning-oriented high-level thinking skills or Higher Order Thinking Skills (HOT). The program was developed in an effort to improve the quality of learning and improving the quality of graduates.

Conceptual learning-oriented high-level thinking skills to overcome levels of Bloom's taxonomy, according to
Resnick(1987: 3) Bloom split into two parts skill, low level of skills and high-level skills. Skills that have a low level of urgency with the learning process, namely remembering, understanding and applying.Meanwhile, high-level skills such as the ability of analyzing, evaluating and creating.

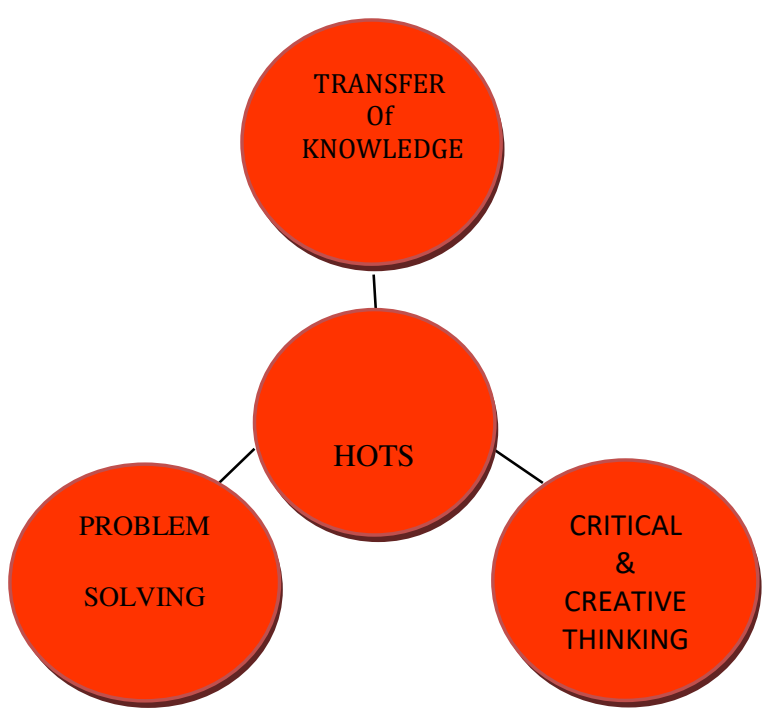

Figure 2. The Aspects of Hinger Order Thinking By: Afandi \& Sajidan (2017)

Early childhood educators should be able to anticipate disruptive era for children aged 0-6 years will now be the strength of the nation in the next 20 years. Training for early childhood educators either independently, or government organizations in the ability of technology, information and communication in order to be able to innovate the learning that takes generations to come.Early childhood educators now are a teacher who lived in the time children are born surrounded by digital means. They are part of a global change in which early childhood teachers acts as a companion they enter the world.

\section{CONCLUSION AND SUGGESTIONS Conclusions}

Based on the discussion of literacy research and obtained the following conclusions: (1) Charged readiness of early childhood teachers in the face of this disruptive era. (2). Early childhood teachers must be able to perform a number of innovations to learning in which information and communication technology is growing fast. (3). Early childhood teachers must have the characteristics to become facilitators for students to have the Higher Order Thinking and prepared for their future. 


\section{Suggestions}

Based on the discussion of literacy research and advice obtained as follows: (1) early childhood teachers must be prepared to accept the advances of technology, information and communication with the appropriate learning innovation these developments. (2) Teachers of early childhood must equip themselves with the skills and support skills in the classroom teaching. (3). Early childhood teachers characteristic response to an increase in early childhood teachers needed this disruptive era.

\section{REFERENCES}

[1] Afandi \& Sajidan. (2017). Stimulation of HigherOrder Thinking Skills: Concepts and Applications in Learning. Surakarta: UND Press (in press).

[2] Director General GTK Kemendikbud. (2018). Increased competence Learning program guidelines berbasisi Zoning. Jakarta: Kemendikbud.

[3] Hadi, Sutrisno. (1995). Research Methodology. Jakarta: Andi Offset.

[4] Handitya, Binov. (2018). Role of Moral Educators in Developing Nations in the Age of disruptions.

National Seminar on Civic Education UNNES 2 (1), $41-54,2018$

[5] Kusuma, Suherli. (2010). Designing a Scientific Paper. Bandung: Rosdakarya.

[6] Kampylis, P, G. Bocconi, S. Punie, Y. (2012). Towards a mapping framework of ICT-enabled innovation for learning. Luxemburg: Publications Office of the European Union.

[7] Komara, Endang. (2014). Interactive teaching and learning. Bandung; RefikaAditama.

[8] Education Minister. (2014). Permendikbud Number 137 Year 2014 Jakarta; Mendikbud.

[9] Resnick, LB (1987). Educational and Learning to Think. Washington, DC: National Academy Press.

[10] Zubaidah, Siti \& Universities, Ladders \& Malang State. (2018). Know 4C: learning and innovation skills to deal with the industrial revolution 4.01 . 